\title{
General anaesthesia for obstetrics, is it obsolete?
}

Holly A. Muir MD FRCPC

When posed with the question, "Is general anaesthesia for obstetric patients obsolete?," anaesthetists who work in university centres with busy obstetric units would be rather quick to say "yes, very close to obsolete." This would not be the case for the majority of anaesthetists working in regional and community hspitals, where general anaesthesia may still be the preferred, or at least the most common, anaesthetic used for Caesarean and difficult vaginal delivery.

A personally conducted informal poll of obstetric anaesthesia practise in various centres across Canada revealed surprising results (Table I). As expected, the frequency for use of general anaesthesia in teaching centres is low. While in the smaller, non-university based centres the frequency often exceeds that of regional anaesthesia, even for elective operative delivery! This concerns those who work in university centres responsible for the training of the anaesthetists who work in the regional and community hospitals. This poses the questions, "Did they not get the experience needed to administer regional anaesthesia confidently to the parturient for delivery?" or "Did they simply not get the message about the potential for severe maternal/fetal morbidity, and even mortality, associated with the use of general anaesthesia in the parturient?"

Anaesthesia is a specialty where much of our practise focuses on avoiding situations which have the potential for causing complications and morbidity/mortality to our patients. Paradoxically, one may routinely administer general anaesthesia for delivery of a pregnant patient ignoring the risk it carries for potential catastrophe.

Anaesthesia-related incidents continue to make a considerable contribution to maternal morbidity and mortality. Difficult intubation, failure to secure the airway on induction with subsequent acid aspiration, and hypoxic cardiac arrest, continue to be the predominant causes of anaesthetic-related maternal morbidity and mortality. Most of our data on maternal morbidity and mortality is obtained from England and Wales. ${ }^{1,2}$ Data obtained from these reports from the late 70 's and early 80 's revealed maternal mortality as a direct consequence of anaesthetic mishap, to rank third as the cause of maternal death. The most recent report from the triennium 1985-1987 showed a reduction in the number of deaths directly related to anaesthesia mishap. Although the ab- solute number of maternal deaths as a consequence of anaesthesia is lower, the majority of these deaths (seven of eight) were a consequence of difficult intubation on induction, with resulting hypoxia, or subsequent pulmonary acid aspiration, a potentially avoidable event. By far the majority of these mishaps occurred in emergency situations. However, $25 \%$ of these cases occurred following induction of general anaesthesia for elective or nonurgent Caesarean section. Similar data were reported in the state of Michigan in 1980 citing failure to secure the airway as a predominant cause of anaesthetic-related maternal death. ${ }^{3}$

A recent ten-year review of ICU admissions as a result of anaesthetic complications from an obstetrical hospital in Brisbane, Australia, revealed severe anaesthetic complications in one of 932 general anaesthetics vs. one in 4177 regional anaesthetics. ${ }^{4}$ In this period no maternal deaths were reported. Two of the 12 patients admitted to the ICU were as a result of problems with intubation at induction. (The most common reason for anaesthesiarelated admission was suspected allergic reaction to the drugs administered.)

Why is general anaesthesia so hazardous in the obstetric population? To answer this question one needs simply to review the physiological changes of pregnancy, and add to them an additional passenger to whom we owe consideration of the effects of anaesthetic drugs - the foetus (Table II).

These changes pose additional hazards, most of which can be overcome or minimized by undertaking the following measures:

- cricoid pressure to prevent acid regurgitation

- preoxygenation prior to induction of anaesthesia to improve maternal $/$ fetal $\mathrm{O}_{2}$ stores

- pretreatment with clear antacids, $\mathrm{H}_{2}$ blocking agents and metoclopramide to reduce gastric content and increase gastric $\mathrm{pH}$

- left lateral tilt to relieve aortocaval compression

- minimized induction-to-delivery time thus reducing fetal exposure to anaesthetic agents.

From Grace Maternity Hospital and Dalhousie University, 5980 University Avenue, Halifax, Nova Scotia, B3H 4NI. 
TABLE I Type of anaesthetic used for Caesarean section

\begin{tabular}{llllll}
\hline & University $A$ & University $B$ & Regional $A$ & Regional B & Community A \\
\hline Total CS & 1922 & 1107 & 432 & 695 & 178 \\
Epidural & $1733 / 90 \%$ & $1023 / 92 \%$ & $341 / 80 \%$ & $337 / 49 \%$ & $57 / 32 \%$ \\
General & $123 / 6.4 \%$ & $63 / 6 \%$ & $138 / 17 \%$ & $358 / 51 \%$ & $121 / 68 \%$ \\
Combination & $189 / 10 \%$ & & $12 / 20 \%$ & & \\
\hline
\end{tabular}

TABLE II Physiological changes of pregnancy and anaesthetic risk

\begin{tabular}{lll}
\hline Variable changed & Physiological effect & Anaesthetic effect \\
\hline FRC - decreased & Reduced $\mathrm{O}_{2}$ reserve & Rapid desaturation \\
Metabolic rate - increased & High $\mathrm{O}_{2}$ demand & Rapid desaturation \\
Decreased SVR - venous dilatation & 1 Oedema including upper airway and larynx & 1 Difficult intubation and airway trauma \\
& 2 Nerve entrapment & 2 Risk of nerve compression injury \\
Preparation for lactation & Breast enlargement & Difficult intubation \\
Gastrin secretion - increased & Decreased pH of stomach contents & $\begin{array}{c}\text { Increased risk for aspiration and aspiration } \\
\text { pneumonitis }\end{array}$ \\
Abdominal girth - expansion & 1 Increased abdominal pressure & 1 Aspiration \\
Progesterone & 2 Large vessel compression & 2 Hypotension with supine position \\
& 1 Reduced tone in lower oesophageal sphincter & 1 Aspiration \\
& 2 Analgesic effect & 2 Increased sensitivity to anaesthetic agents - both \\
& local and general anaesthetics
\end{tabular}

One element in the equation, however, remains difficult to predict - the ability to secure the airway rapidly, undoubtedly the most essential element of all. The incidence of failed intubation in the obstetric population falls between 1:300 and 1:500, while that of general population is near $1: 2500 .^{5}$

The predictability of intubating the trachea successfully has been an area of interest for many over the years, and a variety of risk factors for difficult intubation has been identified, and classifications devised. One with which we are most familiar is the Mallampati assessment of oropharyngeal structures. ${ }^{6,7}$ In a recent study, however, Rocke et al. demonstrated that external assessment of the parturient's airway does not reliably predict ease of intubation. ${ }^{8}$ In this series of 1500 patients undergoing emergency and elective Caesarean section, he experienced only two failed intubations. However, these patients were judged to have class II and III airways before induction, while none of his patients with class IV airways had failed intubation. Rocke and his colleagues were able to identify factors associated with difficult intubation in the parturient which included poor visualization of oropharyngeal structures, short neck, obesity, missing maxillary and/or single incisors, and receding mandible.
Another potential hazard of general anaesthesia in the parturient is awareness under anaesthesia. In our attempts to ensure brief and limited fetal exposure to anaesthetic agent, the mother may be inadequately anaesthetized. ${ }^{9-11}$ With the currently popular technique for induction and maintenance of general anaesthesia for Caesarean section (Table III), the incidence of awareness may reach 8-10\%. Awareness under anaesthesia can have severe psychological sequelae under normal circumstances; however, this horrifying experience at the delivery of a baby can have additional consequences, including interference in maternal/infant bonding.

The effects on the fetus of general anaesthesia are limited. When comparing neonates delivered by Caesarean section using general or regional anaesthesia differences in adaptive capacity and behavioural scores can be seen at $15 \mathrm{~min}$ and two hours after delivery. However, no differences are detectable $24 \mathrm{hr}$ after delivery. ${ }^{12} \mathrm{~A}$ one minute Apgar $<7$ is seen more frequently in neonates delivered under general than with regional anaesthesia. ${ }^{13}$ Long-term clinical importance of these observations is likely minimal, but in the event of a neonate with other adaptive handicaps, these first minutes of life could have more critical significance.

What are the virtues of general anaesthesia? General 
TABLE III Recommended technique for induction of general anaesthesia in the parturient

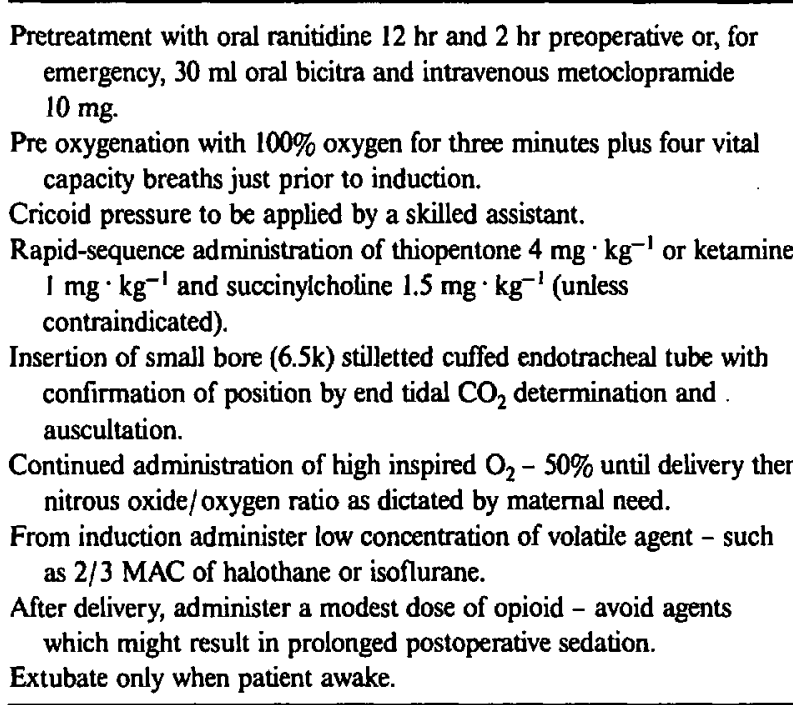

anaesthesia can be induced rapidly, provides reliable operative conditions, maintains haemodynamic stability and usually renders the patient unaware. However, when one looks at the risk vs benefits, general anaesthesia exposes the patient to greater risk of severe morbidity and mortality than an alternative technique of regional anaesthesia.

With due consideration to the risk associated with general anaesthesia there remain situations in which general anaesthesia may be the technique of choice for Caesarean section. However, these are becoming relatively few and many are controversial. Historically these included: severe fetal distress; maternal musculoskeletal abnormality in which entry into the epidural space may be impossible; severe cardiac disease; obstetrical conditions where risk of severe haemorrhage exists; active genital herpes infection; some pre-existing neurological diseases; and the classic contraindications to regional anaesthesia, such as maternal coagulopathy, maternal shock with large volume depletion and no time for correction; skin infection at the site of insertion, sepsis, and patient refusal. With advancement of our knowledge of regional anaesthesia and more widespread experience, the presence of many of these conditions does not necessarily imply that general anaesthesia is the anaesthetic of choice.

Avoiding regional anaesthesia in the face of active herpes grew from a fear of intrathecal spread of the virus. However, recent studies suggest that this is unfounded. ${ }^{14,15}$ Likewise, avoiding regional anaesthesia in the face of preexisting neurological disease is not founded on fact. Rather, it is based on the theoretical concern that one may worsen the disease or, more to the point, if the pa- tients disease progressed on its natural course, the anaesthetists may be implicated. ${ }^{16}$ I think with the current evidence suggesting the potential risk of general anaesthesia to the parturient, it would be difficult to defend the administration of general anaesthesia if a mishap were to occur against a theoretical concern of potential litigation.

The choice of anaesthetic for patients with cardiac disease has broadened over the years. A popular frequently quoted obstetrical anaesthesia text continues to recommend general anaesthesia as the anaesthetic of choice for severe cardiac conditions such as severe aortic stenosis, uncorrected tetrology of fallot, uncorrected coarctation of the aorta and Eisenmenger's syndrome, all for which a large decrease in systemic vascular resistance is contraindicated. ${ }^{17}$ However, reports have appeared of the successful use of regional anaesthesia, when carefully titrated, which avoid decreases in systemic vascular resistance, even in these severe cardiac conditions.

Many anaesthetists would not attempt regional anaesthesia in patients with a history of major structural back surgery, such as Harrington rod insertion. However, our centre's experience and recent reports demonstrate a good success with regional anaesthesia for Caesarean section. ${ }^{18}$ The use of spinal anaesthesia for Caesarean section is recommended over epidural anaesthesia in patients with previous surgery to avoid potential problems with spread of local anaesthetic in the epidural space.

In patients in whom the risk of severe intraoperative bleeding exists, general anaesthesia has traditionally been used to ensure haemodynamic stability. However, once again this has been challenged and regional anaesthesia is used safely in these situations. Although no controlled studies have been done in the obstetrical situation, such as with placenta praevia, the literature suggests for other situations where blood loss can be excessive, that regional anaesthesia may result in a reduction in total blood loss. ${ }^{19}$ Despite some contention that regional anaesthesia may be protective, there are situations involving heavy blood loss where control of the airway, ventilation, and patient unconciousness is desirable. For this reason, I would suggest that if regional anaesthesia is to be used as the first line anaesthetic, before coming to that decision with the patient, a careful assessment of the airway be made and a clear plan formulated to ensure safe intubation, should the need arise.

The role of general anaesthesia in the face of fetal distress must be looked at carefully. Chestnut recently reviewed this issue and suggested that, in many instances of fetal distress, time does exist for the establishment of regional anaesthesia. ${ }^{20}$ In these highly charged situations a careful assessment of the patient's airway is essential 
TABLE IV Recommendations of American College of Obstetricians and Gynecologists on anaesthetic management of obstetric cases

I ACOG acknowledges that failed intubation and pulmonary aspiration of gastric contents remain prominent causes of maternal morbidity and mortality from anaesthesia.

2 ACOG recommends that "the obstetric care team should be alert to the presence of risk factors that place the parturient at increased risk for complications from emergency general or regional anaesthesia."

3 When risk factors are identified, ACOG recommends that the obstetrician obtain antepartum consultation from an anesthesiologist. (For this recommendation to be effective, anesthesiologists should establish procedures to facilitate antepartum consultations.)

4 ACOG recommends that the obstetrician and anaesthesiologist develop "strategies ... to minimize the need for emergency induction of general anaesthesia in women for whom this would be especially hazandous." Such strategies might include early establishment of intravenous access and early placement of an epidural or spinal catheter.

5 In emergency obstetrical cases, ACOG acknowledges that "the maternal as well as the fetal status must be considered." They . further state: "Although there are some situations in which general anaesthesia is preferable to regional anaesthesia, the risk of general anaesthesia must be weighed against the benefit for those patients who have a greater potential for complications."

6 ACOG acknowledges that "Caesarean deliveries that are performed for a nonreassuring fetal heart rate pattern do not necessarily preclude the use of regional anaesthesia."

and general anaesthesia is induced only if one has complete confidence in one's ability to secure the airway.

Contraindications to regional anaesthesia exist. However, many of these have begun to soften over the years especially in obstetrical cases where the benefits of regional anaesthesia so often outweigh the risk.

In the obstetrical population, most problems with coagulation involve the amount or function of platelets in circulation. Controversy continues to exist concerning the level or degree of abnormality at which regional anaesthesia can be safely practiced. It is now accepted that a platelet count of less than $100,000 \mathrm{~mm}^{-3}$ is a contraindication to regional anaesthesia, and is no longer valid. The validity of a bleeding time as a measure of a patient's potential to bleed is questionable. ${ }^{21}$ Thromboelastography will likely have a limited application in obstetrical patients. Most experts support an individual approach to the patients advocating consideration of the risks vs benefits of regional anaesthesia or the alternatives (i.e., general anaesthesia), and perform a careful history and physical examination looking for tangible evidence of abnormal bleeding or clotting before deciding to withhold regional anaesthesia. ${ }^{22}$

Patients who exhibit signs of considerable volume de- pletion in whom there is no time for correction, continue to pose an indisputable contraindication to regional anaesthesia, as maternal cardiovascular collapse after administration of regional anaesthesia can have devastating consequences. However, when time allows, correction of the maternal volume deficit with the aid of central pressure monitoring and subsequent careful titration of local anaesthetic to achieve block can be done safely.

Maternal skin infection at the site of insertion and maternal sepsis without shock as contraindications to regional anaesthesia require some consideration. Firstly, one must keep in mind that rashes and skin eruptions in pregnancy are common and not always infective. Secondly, the chance of introducing organisms with an epi$\mathrm{dural} / \mathrm{spinal}$ needle is very low, and thirdly, in most nonimmune compromised patients the body's defence mechanisms would be able to protect against infection. With maternal sepsis one must keep in perspective that a large number of patients have had their intrathecal space violated with a needle in a septic state in the form of diagnostic lumbar puncture without apparent consequence. In summary, once again in these instances the risks versus benefits of regional anaesthesia versus alternative techniques must be examined.

Finally the issue of patient refusal as a contraindication to regional anaesthesia must be examined. From a medical legal point of view this stands as the strongest contraindication. However, when one encounters a patient who absolutely refuses regional anaesthesia for Caesarean section, one must examine one's own and the community health educator's ability to educate their patients. Many of the cases of patient refusal would be rectified with a strong effort to provide community education (both medical and lay) on the risks and benefits of anaesthetic techniques for Caesarean section.

In my opinion, little controversy exists that regional anaesthesia is the preferred anaesthetic for Caesarean section. However, I do recognize that, in many situations, it may often not be convenient or easy to use regional anaesthesia. The American College of Obstetricians and Gynecologists has recently made some recommendations, directed at both anaesthetists and obstetricians, urging them to modify their practise habits and those of their obstetrical unit, to reduce the need for general anaesthesia. Chestnut has nicely summarized these recommendations as they apply to the practise of obstetric anaesthesia ${ }^{23}$ (Table IV).

In summary, while it would be wrong to say that general anaesthesia for Caesarean section has become obsolete, contraindications to regional anaesthesia do exist and general anaesthesia is the preferred anaesthetic. However, the widespread use of general anaesthesia for Cae- 
TABLE $V$ Benefits of regional anaesthesia for the parturient

Airway reflexes remain intact, thus reducing risk of aspiration.

Spontaneous respiration maintained, thus reducing the need for airway manipulation, loss of airway and hypoxia.

Reduces exposure of both mother and fetus to anaesthetic agents, with reduced likelihood of adverse drug reaction or depressed neonate.

Mother is awake and alert, able to bond with neonate immediately after delivery and establish breast feeding earlier.

Mother is able to experience benefits of intraspinal opioids for postoperative pain relief.

Reduced postoperative morbidity compared with general anaesthesia with factors such as pain, sore throat, gastrointestinal function, respiratory function, pyrexia and depressed mood.

sarean section should be discouraged. Anaesthetists practising obstetrical anaesthesia should make an effort to practise and refine their regional anaesthesia skills at all opportunities, become actively involved in the day-to-day management of their obstetrical service and enthusiastically educate their obstetricians, family physicians, nursing staff and lay community about the risks of general anaesthesia and benefits of regional anaesthesia ${ }^{24}$ (Table v).

When the need to administer general anaesthesia to the parturient does arise, the anaesthetist, nursing staff and obstetrician should all be conscious of the risk that this imposes to the patient. The primary concern should focus on the patient's airway and confidence in the ability to secure the airway rapidly. If any doubt exists of the ability to intubate the trachea a rapid-sequence induction of general anaesthesia should not be embarked upon but, instead, a plan should be implemented to secure the airway with the patient awake. Should unanticipated difficulty arise the entire team must be ready to respond with a predetermined plan for the failed or difficult intubation. 5,25

\section{References}

1 Report on confidential enquiries into maternal deaths in England and Wales 1979-1981. London: Her.Majesty's Stationery Office, May 1986.

2 Report on confidential enquiries into maternal deaths in England and Wales 1985-87. London: Her Majesty's Stationery Office, 1991.

3 Endler GC, Mariona FG, Sokol RJ, Stevenson LB. Anesthesia-related maternal mortality in Michigan, 1972 to 1984. Am J Obstet Gynecol 1988; 159: 187-93.

4 Stephens ID. ICU admission from an obstetrical hospital. Can J Anaesth 1991; 38: 677-81.

5 Davies JM, Weeks $S$, Crone LA, Pavlin E. Difficult intubation in the parturient. Can J Anaesth 1989; 36: 668-74.
6 Mallampati $S R$. Clinical sign to predict difficult tracheal intubation (hypothesis) (Letter). Can Anaesth Soc J 1983; 30: 316-7.

7 Mallampati SR, Gatt SP, Gugino LD, et al. A clinical sign to predict difficult tracheal intubation: a prospective study. Can Anaesth Soc J 1985; 32: 429-34.

8 Rocke DA, Murray WB, Rout CC, Gouws E. Relative risk analysis of factors associated with difficult intubation in obstetric anesthesia. Anesthesiology 1992; 77: 67-73.

9 Lyons G, Macdonald R. Awareness during Caesarean section. Anaesthesia 1991; 46: 62-4.

10 Schultetus RR, Hill CR, Dharamraj CM, Banner TE, Berman $L S$. Wakefulness during cesarean section after anesthetic induction with ketamine, thiopental, or ketamine and thiopental combined. Anesth Analg 1986; 65: 723-8.

11 Baraka A, Louis F, Noueihid R, Diab M, Dabbovs A, Sibai $A$. Awareness following different techniques of general anaesthesia for Caesarean section. Br J Anaesth 1989; 62: 645-8.

12 Shnider SM, Levinson G. Anesthesia for Cesarean section. In: Shnider SM, Levinson G (Eds.). Anesthesia for Obstetrics, 3rd ed. York, PA: Williams \& Wilkins, 1993; 211-45.

13 Evans CM, Murphy JF, Gray OP, Rosen M. Epidural versus general anaesthesia for elective Caesarean section. Effect on Apgar score and acid-base status of the newborn. Anaesthesia 1989; 44: 778-82.

14 Bader AM, Camann WR, Datta S. Anesthesia for cesarean delivery in patients with herpes siplex virus type- 2 infections. Reg Anesth 1990; 15: 261-3.

15 Crosby ET, Halpern SH, Rolbin SH. Epidural anaesthesia for caesarean section in patients with active recurrent genital herpes simplex infections: a retrospective review. Can $\mathbf{J}$ Anaesth 1989; 36: 701-4.

16 Glosten B. Anesthesia and coexisting maternal disease. Pt. 2: Diabetes mellitus, obesity, and pulmonary and neurologic disease. In: Norris MC (Ed.). Obstetric Anesthesia, Philadelphia: J.B. Lippincott Company 1993; 473-99.

17 Mangano DT. Anesthesia for the pregnant cardiac patient. In: Shnider SM, Levinson G (Eds.). Anesthesia for Obstetrics, 3rd ed. York, PA: Williams \& Wilkins, 1993: 485-523.

18 Crosby ET, Halpern SH. Obstetric epidural anaesthesia in patients with Harrington instrumentation. Can $\mathbf{J}$ Anaesth 1989; 36: 693-6.

19 Kehlet $H$. General vs regional anesthesia. In: Rogers MC, Tinker JH, Covino BG, Longnecker DE (Eds.). Principles and Practice of Anesthesiology, vol 2. Toronto: Mosby Year Book 1993; 1218-34.

20 Chestnut $D H$. Fetal monitoring and anaesthesia for fetal distress. Can J Anaesth 1993; 40: R74-80.

21 Rodgers RP, Levin J. A critical reappraisal of bleeding time. Semin Thromb Hemost 1990; 16: 1-20.

22 Rocke DA, Rout CC, Orlikowski CEP. Anesthesia and 
coexisting maternal disease, pt. 1: cardiac and hematologic disease. In: Norris MC, editor. Obstetric Anesthesia, Philadelphia: J.P. Lippincott Company 1993, 447-73.

23 Chestnut $D H$. Anesthesia for the high risk obstetric patient. American Society of Anesthesiologists Annual Refresher Course Lectures 1992; 511.

24 Morgan BM, Aulakh JM, Barker JP, Reginald PW, Goroszeniuk $T$, Trojanowski $A$. Anaesthetic morbidity following Caesarean section under epidural or general anaesthesia. Lancet 1984; 11: 328-30.

25 Benumof JL. Management of the difficult airway: the ASA algorithm. American Society of Anesthesiologists Annual Refresher Course Lectures 1993; 531. 


\section{L'anesthésie générale obstétricale, est-elle devenue obsolète?}

Holly A. Muir MD FRCPC

Les anesthésistes qui exercent dans les grands départements universitaires d'obstétrique s'empressent de répondre affirmativement à cette question. Par contre, ceux qui exercent dans les hôpitaux régionaux et communautaires ne semblent pas d'accord, car ils continuent d'administrer l'anesthésie générale pour la césarienne et l'accouchement vaginal difficile.

Une enquête personnelle portant sur la pratique de l'anesthésie obstétricale a donné des résultats surprenants (Tableau I). Comme prévu, la fréquence de l'anesthésie générale dans les hôpitaux d'enseignement est faible. Dans les hôpitaux plus petits, sans vocation universitaire, sa fréquence dépasse souvent celle de la régionale, même pour les césariennes programmées. Ceci inquiète les universitaires responsables de la formation des anesthésistes qui exercent en région. Les questions suivantes viennent naturellement: ces anesthésistes, ont-ils acquis la compétence nécessaire pour administrer avec assurance l'anesthésie régionale en obstétrique? Comprennent-ils les graves dangers que l'anesthésie générale fait courir aussi bien à la mère qu'à l'enfant?

L'anesthésie est une discipline essentiellement axée sur la prévention des complications et de la mortalité. Cependant, aussi paradoxal que celui puisse paraitre, il est possible d'administrer l'anesthésie générale pour une naissance sans en connaître les risques.

Les incidents associés à l'anesthésie contribuent toujours pour une part importante à la morbidité et à la mortalité maternelles. L'intubation difficile, l'impossibilité d'assurer la perméabilité des voies aériennes à l'induction avec aspiration acide subséquente, et l'arrêt cardiaque hypoxique sont toujours les causes principales de la morbidité et de la mortalité maternelles reliées à l'anesthésie. La plupart des données nous sont parvenues de l'Angleterre et du pays de Galles. ${ }^{1,2}$ Les études des années 70 et ' 80 ont révélé que la mortalité maternelle causée par les accidents anesthésiques figuraient au troisième rang des causes de mortalité maternelle. A ce sujet, le rapport le plus récent portait sur les années 1985-1987 et révélait une baisse du taux de mortalité reliée à l'anesthésie générale. Bien que le nombre absolu des décès maternels fut plus bas, la majorité de ceux-ci (sept sur huit) étaient consécutifs a un accident évitable, comme lintubation difficile avec hypoxie ou aspiration pulmo- naire. Ces incidents survenaient pour la plupart en situations d'urgence, mais $25 \%$ survenaient à l'induction de l'anesthésie générale pour une césarienne non urgente programmée. En 1980, des données identiques compilées au Michigan, confirment que l'impossibilité de maintenir la perméabilité des voies aériennes représente la principale cause de décès maternel relié à l'anesthésie. ${ }^{3}$

Une étude récente étalée sur dix ans et réalisée à Brisbane dans un hôpital obstétrical australien porte sur les admissions aux soins intensifs consécutives à des complications anesthésiques. Cette étude rapporte une complication grave pour 932 anesthésies générales comparativement à une pour 4177 anesthésies régionales. ${ }^{4}$ On n'a pas rapporté de morts maternelles pendant cette période. Deux des 12 patientes ont été admises à l'USI à la suite de difficultés d'intubation. La possibilité d'une réaction allergique aux médicaments constituait la raison la plus fréquente des admissions.

Pourquoi l'anesthésie générale est-elle si dangereuse en obstétrique? Pour répondre à cette question, il faut se rappeler les changements physiologiques de la grossesse, et ajouter un passager bien particulier qui mérite toute notre attention, le foetus (Tableau II).

On diminue considérablement le risque de complications provoqué par ces changements en appliquant les mesures suivantes:

- la compression externe du cricoïde pour prévenir la régurgitation acide;

- la préoxygénation avant l'induction pour augmenter la réserve en $\mathrm{O}_{2}$;

- la préparation aux antiacides clairs, aux inhibiteurs $\mathbf{H}_{2}$ et à la métoclopramide pour diminuer le contenu gastrique et augmenter le $\mathrm{pH}$;

- la surélévation du coté droit pour diminuer la compression aortocave;

- le raccourcissement de l'intervalle induction-sortie du foetus.

Un élément du plan d'action demeure toutefois imprévisible: la capacité de protéger la filière aérienne, qui constitue sans doute le pivot de l'induction. Lincidence de l'échec de l'intubation se situe entre 1:300 et 1:500 en obstétrique, et dans la population générale à $1: 2500 .^{5}$

Prédire le succès de l'intubation suscite l'intérêt des anesthésistes depuis longtemps. Des facteurs de risque ont 
TABLEAU I Méthodes anesthésiques utilisées pour la Césarienne

\begin{tabular}{lllllc}
\hline & Université $A$ & Université B & Région A & Région B & Communauté A \\
\hline Total & 1922 & 1107 & 432 & 695 \\
Epidurale & $1733 / 90 \%$ & $1023 / 92 \%$ & $342 / 81 \%$ & $337 / 49 \%$ & 178 \\
Générale & $123 / 6,4 \%$ & $63 / 6 \%$ & $138 / 17 \%$ & $35 / 32 \%$ \\
Association & $189 / 10 \%$ & & $12 / 20 \%$ & $121 / 68 \%$ \\
\hline
\end{tabular}

TABLEAU II Changements physiologiques de la grossesse et le risque anesthésique

\begin{tabular}{lll}
\hline Paramètre & Effet physiologique & Effet anesthésique \\
\hline Baisse de la CRF & Baisse de la réserve do $\mathrm{O}_{2}$ & Désaturation rapide \\
Augmentation du métabolisme basal & Augmentation de la demande en $\mathrm{O}_{2}$ & Désaturation rapide \\
Baisse du retour veineux & 1 Oedème des voies respiratoires et du larynx & 1 Intubation difficile et traumatique \\
& 2 Compression nerveuse & 2 Risque de lésion nerveuse \\
Lactogénèse & Expansion des seins & Intubation difficile \\
Augmentation de la sécrétion de gastrine & Baisse du pH gastrique & $\begin{array}{c}\text { Augmentation du risque d'aspiration et de } \\
\text { pneumonie }\end{array}$ \\
Expansion du tour de taille & 1 Augmentation de la pression abdominale & 1 Aspiration \\
Progestéronémie & 2 Compression des gros vaisseaux & 2 Hypotension de décubitus \\
& 1 Diminution du tonus du sphincter oesophagien & 1 Aspiration \\
& 2 Effet analgésique & 2 Augmentation de la sensibilité aux agents \\
& 3 Ralentissement du transit gastrique avec & 3 Aspiration locaux et généraux \\
\hline
\end{tabular}

été identifiés et classifiés. La classification la mieux connue est celle de Mallampati qui intéresse les structures oropharyngées. $^{6,7}$ Plus récemment, Rocke et al. ont montré que l'examen externe des voies aériennes de la parturiente ne prédisait pas réellement si l'intubation sera difficile. ${ }^{8}$ Dans sa série de 1500 parturientes soumises à des césariennes réglées ou urgentes, il n'a constaté que deux échecs à l'intubation. Avant l'induction, ces patientes étaient classifiées II et III, mais aucune n'était de la classe IV. Rocke et al. ont identifié les facteurs associés à l'intubation difficile de la parturiente: la pauvre visualisation des structures oropharyngées, la brièveté du cou, l'obésité, les anomalies maxillo-dentaires et la retrognathie.

Le retour à la conscience pendant la césarienne représente un des à-cotés pénibles de l'anesthésie générale. En tentant de diminuer l'exposition du foetus aux anesthésiques, il arrive qu'on n'approfondisse pas suffisamment l'anesthésie. " Avec les méthodes actuelles (Tableau III) d'induction et d'entretien de l'anesthésie générale pour la césarienne, l'incidence des reprises de conscience peut atteindre $8-10 \%$. Cette complication peut comporter des séquelles psychologiques importantes tout en étant nocive pour le lien qui doit s'établir entre la mère et l'enfant.

Si on compare les nouveaux-nés extraits par césarienne sous anesthésie régionale avec ceux qui naissent sous anesthésie générale, on constate que les effets foetaux de la générale sont minimes. Les différences de capacité d'adaption et de mesures comportementales sont considéra- bles à $15 \mathrm{~min}$ et deux heures de la naissance, mais elles ne se retrouvent plus après $24 \mathrm{~h} .^{12} \mathrm{Un}$ Apgar $1 \mathrm{~min}<7$ est plus fréquent sous anesthésie générale que sous régionale. ${ }^{13}$ A long terme, ces différences sont négligeables, mais si le nouveau-né naît avec des tares, ces premières minutes de vie prennent beaucoup d'importance.

L'anesthésie générale présente plusieurs avantages. On peut l'induire rapidement, elle procure de bonnes conditions opératoires, elle maintient la stabilité hémodynamique et généralement procure l'inconscience. Cependant, quand on pèse le risque contre le bénéfice, l'anesthésie générale expose la parturiente à un risque plus élevé de morbidité et de mortalité que l'alternative régionale.

Malgré cela, il n'en demeure pas moins que, dans certaines circonstances, l'anesthésie générale demeure la technique de choix pour la césarienne. Cependant ces situations sont plutôt rares et certaines sont même discutables. Elles sont: la détresse foetale grave; les anomalies musculosquelettiques qui empêchent d'accéder à l'espace épidural; les maladies cardiaques graves; le risque d'hémorragie obstétricale; l'herpès génital; certaines maladies neurologiques, les contre-indications habituelles de l'épidurale, comme la coagulopathie maternelle; le choc hypovolémique; le sepsis et, finalement, le refus de la mère. Avec les progrès de anesthésie régionale, certaines de ces contre-indications sont désuètes et ne commandent plus une anesthésie générale systématique.

En presence de l'herpès génital actif, on a craint la conta- 
TABLEAU III Technique recommandée pour linduction de l'anesthésie chez la parturiente

Préparation à la ranitidine orale $12 \mathrm{~h}$ et $2 \mathrm{~h}$ avant lintervention, ou en urgence, $30 \mathrm{ml}$ de bicitra oral et métoclopramide $10 \mathrm{mg} i v$.

Préoxygénation avec $\mathrm{O}_{2} 100 \%$ pour $3 \mathrm{~min}$ et 4 inspirations forcées immédiatement avant l'induction.

Pression sur le cricoïde appliquée par un assistant habitué.

Administration en séquence rapide de thiopentone $4 \mathrm{mg} \cdot \mathrm{kg}^{-1}$ ou de kétamine $1 \mathrm{mg} \cdot \mathrm{kg}^{-1}$ et de succinylcholine $1,5 \mathrm{mg} \cdot \mathrm{kg}^{-1}$ (si non contre-indiquée).

Insertion à l'aide d'un stylet d'une canule endotrachéale de faible calibre $(6,5)$ avec ballonnet gonflable suivie de la confirmation de la position par le capnographe et l'auscultation.

Continuer l'administration d'une concentration élevée d $\mathrm{O}_{2}-50 \%$ jusqu'à la délivrance et par la suite du $\mathrm{N}_{2} \mathrm{O} / \mathrm{O}_{2}$ selon les besoins maternels.

Après l'induction, administrer un agent volatil comme l'halothane ou l'isoflurane à 0,6 MAC.

Après la sortie du foetus, administrer une petite dose de morphinique. Eviter les drogues qui prolongent la sédation postopératoire.

N'extuber que lorsque la patiente est éveillée.

mination virale des méninges: cette crainte, comme le démontrent des études récentes, n'était pas fondée. ${ }^{14,15} \mathrm{On}$ peut dire la même chose des maladies neurologiques préexistantes. Dans ces cas, linquiétude reposait sur la crainte d'aggraver la maladie et surtout, de se voir blâmer pour des complications survenues dans le cours normal de la maladie. ${ }^{16} \mathrm{Je}$ crois qu'avec le risque potentiel de l'anesthésie générale chez la parturiente, il serait difficile de défendre sa décision si un ennui grave survenait, sous le seul prétexte théorique qu'un litige était appréhendé.

Un texte fréquemment cité en anesthésie obstétricale favorise l'anesthésie générale dans certaines affections cardiaques graves comme la sténose mitrale, la tétralogie de Fallot, la coarctation de l'aorte et le syndrome d'Eisenmenger. Dans toutes ces affections, une chute importante de la résistance vasculaire systémique peut être catastrophique. ${ }^{17}$ Cependant, des études on rapporté qu'il est possible, même dans ces conditions, de réaliser une anesthésie régionale sans problèmes, et sans réduction importante de la résistance vasculaire systémique.

Plusieurs anesthésistes évitent l'anesthésie régionale chez les patients qui ont des antécédents de chirurgie lombaire majeure, comme linsertion d'une tige de Harrington. Cependant notre expérience et celle de plusieurs cliniciens révèlent un taux de réussite élevé pour la césarienne sous régionale dans ces conditions. ${ }^{18} \mathrm{La}$ rachianesthésie est recommandée pour les parturientes qui ont déjà subi une chirurgie vertébrale étendue, pour prévenir le problème que causerait linsuffisance de diffusion de l'anesthésique local dans l'espace épidural.

Chez la patiente à risque d'hémorragies peropératoires, on a traditionnellement administré l'anesthésie générale pour assurer la stabilité hémodynamique. Cependant, encore là, cette tradition est contestée et on a eu recours à l'anesthésie régionale sans problèmes dans cette situation. Bien qu'il n'existe pas d'études contrôlées portant sur des pathologies obstétricales spécifiques comme le placenta praevia, la littérature suggère que, dans d'autres situations où les pertes sanguines sont excessives, la régionale peut même diminuer les pertes sanguines. ${ }^{19}$ Malgré la présumée supériorité de l'anesthésie régionale, il se présente des cas d'hémorragies graves où le contrôle de la filière aérienne, la ventilation et linconscience sont essentielles. Pour cette raison, il est suggéré d'utiliser la régionale comme anesthésie de première ligne, mais avant de parvenir à une décision avec la patiente, il faut faire un bilan complet des voies aériennes et dresser un plan concret pour intuber en toute sécurité, si le besoin se faisait sentir.

Il faut examiner soigneusement le rôle de l'anesthésie générale au regard de la détresse foetale. Chestnut qui a récemment étudié ce problème suggère que, dans certains cas de détresse foetale, le temps ne jouait pas en faveur de l'anesthésie régionale. ${ }^{20}$ Dans ces situations très critiques, une évaluation soignée des voies aériennes est encore essentielle avant linduction de l'anesthésie générale, qui ne sera initiée qui si on est absolument sûr de son habileté à maintenir les voies aériennes ouvertes.

Il existe des contre-indications à l'anesthésie régionale. Cependant plusieurs de celles-ci se sont assouplies en obstétrique où les bénéfices de la régionale surclassent les risques de la générale.

En obstétrique, la majorité des problèmes de coagulation sont en rapport avec le nombre et l'intégrité fonctionnelle des plaquettes en circulation. Le degré d'anomalie acceptable pour la réalisation dune régionale demeure sujet à controverse. Aujourd'hui, on accepte généralement qu'une numération des plaquettes inférieure à 100,000 ne contre-indique plus systématiquement la régionale. La validité du temps de saignement comme mesure du potentiel hémorragique est aussi mise en doute. ${ }^{21}$ La thromboélastographie serait vraisemblablement peu utile en obstétrique. La plupart des experts soutiennent une approche individualisée pour chaque patiente et conseille de bien peser le risque contre le bénéfice de la régionale et de son alternatif. La décision d'annuler une régionale doit d'abord reposer sur la recherche, dans lhistoire et l'examen physique, de preuves tangibles de saignement anormal ou d'anomalies de la coagulation. ${ }^{22}$

L'hypovolémie grave qu'on n'a pas le temps de corriger continue de représenter une contre-indication indiscutable à l'anesthésie régionale. Le collapsus cardiovasculaire survenant après l'administration de l'anesthésie régionale peut avoir des conséquences désastreuses. Cependant, si le temps le permet, la correction du déficit volémique 
TABLEAU IV Recommandations de l'ACOG* sur la gestion anesthésique des cas d'obstétrique

1 L'ACOG reconnaît que l'échec de l'intubation et l'aspiration pulmonaire du contenu gastrique demeurent les causes principales de morbidité et de mortalité anesthésique.

2 L'ACOG recommande que l'equipe obstétricale soit informée de la présence de facteurs qui imposent à la parturiente en urgence un risque accru de complications par l'anesthésie générale ou régionale.

3 Une fois les facteurs de risque identifiés, l'ACOG recommande que l'obstétricien demande une consultation anesthésique antepartum (pour que cette recommandation soit efficace les anesthésistes doivent établir un cheminement qui favorise les consultations).

4 L'ACOG recommande que l'obstétricien et l'anesthésiste élaborent des stratégies pour réduire au minimum le recours à une induction d'urgence de l'anesthésie générale chez les parturientes pour qui elle serait périlleuse. Ces stratégies pourraient signifier l'installation précoce d'un accès veineux et d'un cathéter épidural.

5 En cas d'urgence obstétricale, l'ACOG reconnaît que la condition maternelle comme la condition foetale doit être prises en considération. Bien que sous certaine conditions, l'anesthésie générale est préférable à la régionale, le risque de l'anesthésie générale chez la patiente à rique élevé doit être pesé contre ses bénéfices.

6 L'ACOG reconnaît que l'extraction césarienne décidée pour un rythme cardiaque foetal inquiétant n'exclut pas nécessairement l'utilisation de l'anesthésie régionale.

*ACOG: American College of Obstetricians and Gynecologists

maternel contrôlée par la tension veineuse centrale et un dosage minutieux de l'anesthésique local permetent de réussir le bloc sans augmenter les risques.

La contre-indication de la régionale pour cause d'infection cutanée du site de ponction ou de septicémie maternelle sans décompensation hémodynamique mérite un examen attentif. D'abord, il faut retenir que, pendant la grossesse, les érythèmes et éruptions cutanées sont fréquents sans être nécessairement infectieux; ensuite, que les chances d'introduire un micro-organisme avec l'aiguille rachidienne ou épidurale sont minces, et que, finalement, chez la plupart des patientes immunocompétentes, les mécanismes naturels de défense protègent contre l'infection. En cas de sepsis, il faut aussi réaliser que plusieurs patientes ont déjà subi une ponction lombaire sans conséquences apparentes. En résumé, c'est encore l'appréciation de la relation risque/bénéfice qui déterminera si on administre une régionale ou non.

Finalement, que dire du refus de la patiente? Du point de vue médico-légal, il représente évidemment la plus sérieuse des contre-indications. Cependant, lorsqu'une patiente refuse absolument l'anesthésie régionale pour une césarienne, il faut s'interroger sur sa capacité personnelle dinformer et la compétence de ceux/celles qui font l'éducation de la parturiente. Beaucoup de refus seraient évités si on faisait un effort d'éducation auprès de la communauté (sans oublier les médecins) sur les risques et bénéfices des techniques anesthésiques pour la césarienne.
TABLEAU V Bénéfices de l'anesthésie régionale pour la parturiente

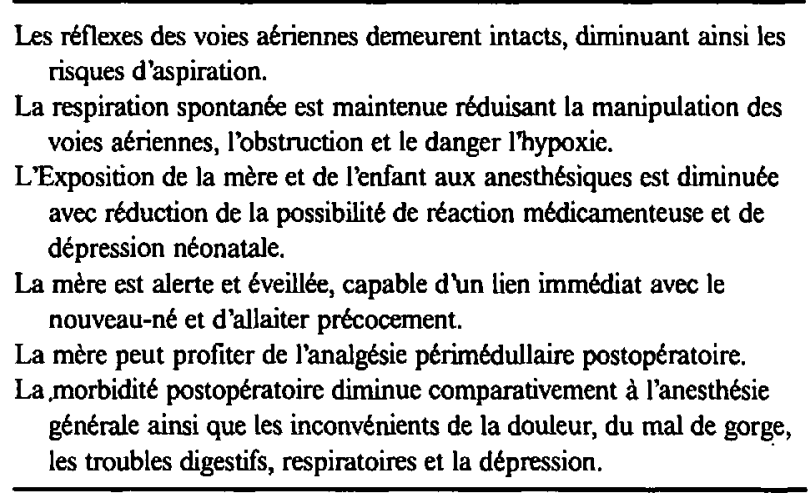

Dans mon esprit, il ne fait aucun doute que pour la césarienne, l'anesthésie régionale est préférable. Je reconnais toutefois, que dans plusieurs situations, elle peut s'avérer contre-indiquée et difficile à administrer. Le Collège américains des obstétriciens et gynécologues (ACOG) vient de faire des recommandations à l'intention des anesthésistes et des obstétriciens, les engageant à modifier leurs habitudes de pratique et celles des services d'obstétrique afin de diminuer l'utilisation de l'anesthésie générale. Chestnut a résumé ces recommandations et leurs applications à l'anesthésie et à l'obstétrique ${ }^{23}$ (Tableau IV).

En résumé, il est faux d'affirmer que l'anesthésie générale soit devenue obsolète en obstétrique. Il existe toujours des contre-indications à la régionale et des préférences pour la générale. Cependant, l'utilisation abusive de l'anesthésie générale doit être combattue. Les anesthésistes obstétricaux doivent s'efforcer de perfectionner leur habileté et leur dextérité pour la régionale, de simpliquer activement dans la gestion quotidienne des services obstéticaux et de renseigner les obstétriciens, les médecins de famille, le personnel infirmier et les non initiés sur les risques de l'anesthésie générale et les bénéfices de la régionale ${ }^{24}$ (Tableau V).

Quand survient la nécessité d'administrer une anesthésie générale à une parturiente, l'anesthésiste, le personnel infirmier et l'obstétricien doivent être conscient du risque qu'elle comporte pour la patiente. Notre premier souci doit être dirigé vers lintégrité des voies aériennes et vers notre capacité de les maintenir ouvertes. Lorsqu'une induction à séquence rapide s'avère périlleuse, l'intubation vigile est indiquée. Si une difficulté non anticipée se présente, toute l'équipe doit être prête à réagir en suivant avec un plan prédéterminé pour l'intubation difficile et son échec. ${ }^{5,25}$

\section{Références \\ (Voir page $\mathrm{R} 24$ )}

